\title{
ARTISTS' MOBILITY IN THE EU: BETWEEN OPPORTUNITIES AND IMPEDIMENTS
}

\author{
Kristina TOPLAK
}

COBISS 1.02

\begin{abstract}
Artists' mobility in the EU: Between Opportunities and Impediments ${ }^{1}$

Mobility, especially labour mobility, is being promoted and highly praised as an economic and political cornerstone of the European Union, essential for its future development and growth. At the same time, people on the move are faced with many impediments to mobility, artists active in transnational art worlds being particularly vulnerable in this respect. Analysing and comparing various written sources (text and hypertext), the author focuses on the international mobility of artists in and to the European Union. The aim of the article is twofold: to outline artists' mobility as a particular type of mobility, and to highlight the divergences between praising of the mobility concept on the decision-making level and the 'naturalization' of mobility in academic discourse on one side and the critical assessment of artists' mobility and impediments to it by art practitioners and experts on the other.
\end{abstract}

KEY WORDS: mobility, artists' mobility, European Union, impediments to mobility

\section{IZVLEČEK}

\section{Mobilnost umetnikov v EU: Med priložnostmi in ovirami}

Mobilnost, zlasti delovna mobilnost, je promovirana in ovrednotena kot ekonomski in politični temeljni kamen Evropske unije in hkrati predstavljena kot ključna za njuna prihodnja razvoj in rast. Mobilni posamezniki pa se hkrati soočajo z veliko ovirami, ki jim preprečujejo mobilnost, pri čemer so umetniki, aktivni v transnacionalnih umetnostnih svetovih, še zlasti ranljivi. Avtorica se $\mathrm{v}$ preglednem članku osredotoča na mednarodno mobilnost umetnikov v Evropski uniji, pri čemer analizira različne pisne vire (literaturo in spletne vire). Članek ima dva namena: orisati mobilnost umetnikov kot posebno obliko mobilnosti in osvetliti razkorak, ki nastaja med dojemanjem mobilnosti, kot jo oblikujejo politični in javni diskurz ter akademski pristopi $\mathrm{k}$ njenemu preučevanju in kot jo definirajo ter problematizirajo umetniki in strokovni delavci v analizah stanja na področju mobilnosti umetnikov.

KLJUČNE BESEDE: mobilnost, mobilnost umetnikov, Evropska unija, ovire mobilnosti

PhD in Ethnology, Research Fellow, Scientific Research Centre of the Slovenian Academy of Sciences and Arts, Slovenian Migration Institute, Novi trg 2, SI-1000 Ljubljana; ktoplak@zrc-sazu.si.

1 The article is a result of the research programme National and Cultural Identity of Slovenian Emigration in the Context of Migration Studies, ID P5-0070 and part of the project Art in diaspora: Anthropological research of creativity among Slovenians in Argentina in return migrants, ID BI-AR/15-17-010. The author acknowledges the receipt of financial support for the programme and the project from the Slovenian Research Agency. 


\section{MOVING BETWEEN PAST AND PRESENT: AN INTRODUCTION}

Throughout history (and the history of art), musicians, painters, writers, architects and many other artists have been depicted as travellers, as people who tend to move around, and have often crossed the borders of European empires, kingdoms or modern states, not only to find work and new patronage, but also seeking inspiration and new experiences, to research and study or to teach others (Klemenčič 2010; Avcioğlu, Flood 2010; Young Kim 2014; Čoralić et al. 2016). The story of Francisco Robba (1698-1757), the 18th-century Italian sculptor who settled in Ljubljana, is the (hi)story of such a traveller. Born and trained in Venice, he could not find work for some time, and therefore decided to try his luck in the lands of the Holy Roman Empire on the - at that time still - "unconquered market" east of Venice. The important 'pushes' and 'pulls' for Robba included the circumstances of his apprenticeship, ${ }^{1}$ the changed conditions on the Venice art market and the increased interest in the Italian art style in border regions northeast of Venice, especially in Ljubljana and its surroundings (Jaki 2010). Robba moved to Ljubljana in 1720 and married a local stonemason's daughter. He obtained the legal status of resident of Ljubljana in 1724 . He took over his father-in-law's workshop, and soon gained a leading position as a local sculptor, and until his death he travelled and worked in the region, from Klagenfurt and Trieste to Ljubljana and Zagreb (Klemenčič 2010).

The career trajectory of Francesco Robba could be applied to modern times, as modern mobile artists are driven by similar incentives as their predecessors, with two important exceptions: first, due to changed political circumstances in the late 19th and early 20th century, national boundaries, especially in Europe, changed drastically, and modern nation-states have implemented many administrative measures in order to manage the international movement of people and to protect national borders (which consequently became less easily transited) (Goldin et al. 2011: 70-84; Elliott, Urry 2010: 17); and second, modern mobile practices and forms are much more intensive, flexible, multilayered, complex and diverse due to the development of technology and communication and also due to different economic and political pressures. I am not arguing that people are less mobile nowadays; I am arguing that politically-generated administrative obstacles are increasingly hindering the mobility process compared to previous centuries. With the aim to tackle this unique paradox I will discuss contemporary international geographical mobility, mainly focusing on artists' mobility, its promotion and impediments to it.

By focusing on the mobility rather than the migration of artists, I am able to emphasize the flexible, multidirectional features of artists' movements. Namely, the personal lives of people (artists) that are frequently on the move are tangled in "a complex web of social, cultural and economic networks that can span the globe” (Elliot, Urry 2010: 4). Moreover, when reviewing the literature on the migration of artists I noticed the authors' inability to place artists' movements inside the migration framework. Migration is seen as permanent, occupying the space between one home country and one host country, while mobility includes many short or long-term locations, and is multidirectional and creative (Duester 2013: 110). Mobility also better encapsulates all of the other elements of the global/transnational art

1 Robba had been an apprentice in the workshop of the renowned Italian sculptor Pietro Baratta, who already had plenty of works commissioned outside Italy, for example for Habsburg and Russian rulers or for the Roman Catholic Church at the edge of the Habsburg empire in Gorizia (Italy) (Klemenčič 2010: 14). 
world, namely the mobility of artworks, money, grants and mobility within communications and collaborations (ibid.).

In the first part of the article I will discuss the political and academic perceptions of mobility, emphasizing the abovementioned paradox. In order to be able to reflect on the mobility of artists in this respect, I will also outline the specifics of artists' mobility within the concept of mobility as a whole. In the second part I will discuss the impediments to artists' mobility with the aim of juxtaposing them with the perceptions of mobility on the normative and research levels in order to provide a more comprehensive image of artists' mobility. In the conclusion some observations on the impact of the outlined gap between normative framework and practice are included. The outlines and discussions in the article are based on an analysis and critical assessment of various primary and secondary sources (text and hypertext). These included documents covering the European Union (EU) regulatory framework on labour mobility and the socio-political discourse attached to it (various EU reports, official statements of EU officials, official websites, and the primary legal documents covering labour mobility in the EU were reviewed and compared). In addition, the available academic literature on mobility, and specifically artists' mobility, were examined. Within this limited and incomplete reflection on artists' mobility I mainly reviewed the literature in the fields of art history, cultural studies, anthropology and sociology. The discussion on impediments is based on the content analysis of several research studies, reports and policy recommendations prepared and issued by individual experts or groups of experts, interest groups, NGOs or information networks active in the last ten years in the area of mobility and the arts at the EU level.

\section{MOBILITY: NEOLIBERAL PRAISE, ACADEMIC DISCOURSE AND CRITIQUE OF THE CONCEPT}

Geographical mobility is generally considered to be a global phenomenon and people are increasingly seen as being more mobile compared to previous centuries. However, this does not mean that all people are taking part in the process and/or that there are no obstacles to mobility. According to Zygmunt Bauman, who writes about the global hierarchy of mobility (1998), where there is a bottom with locally stuck people and a top with privileged mobile people (emphasis mine), significantly more people are sedentary than mobile. Considering the case of the EU, the numbers of mobile people are rather moderate: the available data for 2013 show that about $4 \%$ of working-age EU citizens lived in an EU country other than their country of birth, including cross-border workers and posted workers (ECFIN 2015: 19).

The free movement of people is one of the four pillars of the EU's internal market and an integral cornerstone of the mobility concept defined in EU treaties and policies and supported through various EU programmes. ${ }^{2}$ Labour mobility in the EU has been and still is perceived as an increasingly important adjustment mechanism for the European

2 In addition to the free movement of goods, services and capital. Conceptualised as the "free movement of workers", mobility was included in the foundational Treaty of Rome (1957). 
economy and has been increasing over the past two decades (ibid.). ${ }^{3}$ Mobility, especially labour mobility inside the EU, is therefore regulated by several EU agreements and directives that all EU Member States are required to follow, ${ }^{4}$ and is also strongly encouraged and financially supported within various transnational programmes and schemes (for example the European Social Fund or the EU Programme for Employment and Social Innovation $^{5}$ ), and promoted through European employment institutions and tools like the European job mobility portal EURES. The year 2006 was even declared the European Year of Workers' Mobility (Eur-Lex 2006). Paraphrasing the title of one of the reports on artists' mobility prepared by the ERICarts institute: mobility in the EU matters (ERICarts 2008). Despite a certain scepticism towards the free movement of persons (i.e. workers) in the EU, indicated by the fact that many EU-15 states in the post 2004-EU-enlargement periods (2004, 2007 and 2013) implemented transitional restrictions for workers from all EU newcomers, (labour) mobility has also become an integral part of EU political discourse. Its positive image and importance on the economic and social levels are echoed in the statements of important EU representatives. Manuel Barroso, president of the European Commission from 2004-2014, stated: "Mobility, whether it is changing job or moving to another region, town or country, can help Europe to adapt, compete and reap the benefits of the new world economic order" (Barroso 2006). Commissioner Andor in his speech in Ghent emphasized:

I will argue not only that freedom of movement is an individual right, but also that labour mobility makes good economic sense. It contributes to the objectives of the Europe 2020 Strategy by making it easier to fill cyclical and structural labour shortages and offering people opportunities for upward economic and social mobility. (Andor 2014)

Another example is part of the speech Commissioner Thyssen gave in Ireland: "But free movement is not only important as an individual right of each citizen. It is also in our collective interest as Europeans that people are mobile and ready to cross borders" (emphasis original; Thyssen 2015). In addition to political discourse, public discourse has also adopted mobility, i.e. freedom of movement and work in the EU, as the main signifier of the EU, and generally a good thing for European integration, for the labour market i.e. economy,

3 Despite the rising trend, mobility in the EU remains insignificant compared to other economic powers such as the US, where nearly $30 \%$ of the working-age population lives in another state (ECFIN 2015).

4 There are many EU documents regulating the area of labour mobility, and all can be found on the official websites of the European Commission and the Council of the European Union. I have analysed and listed only the most important ones: Regulation EU No 492/2011; Article 3(2) of the Treaty on European Union; Articles 4(2)(a), 20, 26 and 45-48 of the Treaty on the Functioning of the European Union; Directive 2004/38/EC on the right of citizens of the Union and their family members to move and reside freely within the territory of the Member States; Regulation (EU) No 492/2011 on freedom of movement for workers within the Union; Regulation (EC) No 883/2004 on the coordination of social security systems and its implementing Regulation (EC) No 987/2009; the Posting of Workers Directive 96/71/ES and Enforcement Directive 2014/67/EU.

5 As much as EUR 919 million has been invested in the programme for the period 2014-2020, http://ec.europa.eu/social/main.jsp?catId=1081\&langId=en. 
and also a good thing for individuals (Vandenbrande et al. 2006: 55-58). ${ }^{6}$ The concept of mobility has entered the vocabulary and the agenda of numerous international institutions: Mendolicchio (2013) reports about various research projects, study programmes and many cultural and artistic organizations. Still, there is a paradox connected to the highly acclaimed freedom of movement in the EU, as many administrative and security-related obstacles to free movement are persistently maintained or generated anew, as we shall discuss below. We can summarize this section with Urry's lucid observation that "the freedom of movement, as represented in popular media, politics and the public sphere, is the ideology and Utopia of the twenty-first century" (Elliot, Urry 2010: 8).

In addition to the public and political arenas, the mobility phenomenon has also been extensively discussed and explored in the social sciences and humanities. John Urry and his followers have defined the sociology of mobility and within it various concepts and forms of mobility and distinctive mobile groups, i.e. labour mobility, mobile lives, elite mobilities, marginal mobility, mobile methods (Urry 2000, 2007, 2010; Büscher et al. 2011; Kalčić et al. 2013; Birtchnell, Caletrio 2014). Moreover, they are also mobilizing a new mobilities paradigm (Scheller, Urry 2016). In his ground-breaking book Sociology Beyond Societies: Mobilities for the Twenty-First Century, Urry argues for a "new" sociology that exchanges its traditional basis - the study of society - for the study of diverse modes of movement, i.e. mobility (2000). Despite the resistance of many sociologists to the "mobilities turn" as a main critique of sedentism and deterritorialisation theories (Sheller 2013; Salazar 2017), many have 'fallen under its spell' not only in the field of sociology, but also in geography, transport studies, communications and anthropology.

Influential scholars such as Giddens, Appadurai, Beck and Bauman "theorise contemporary capitalism and globalisation in terms of increasing numbers and varieties of mobility [...]" (Salazar 2017: 6). As such, mobility appears to be self-evidently central to modernity as a key social process; moreover, its specific discourse is adopted in many scholarly arguments. Such discourses either mythologize ${ }^{7}$ the process of mobility through a special "mythological vocabulary" (Pušnik 2014: 15) or, following Salazar (2017), mobility is considered as a natural tendency in society. In the first case, mobility is very hard to define, as it is positioned in the realm of a slippery, or as Pušnik (ibid.) calls it, "mobile" conceptual field. In the latter case, and this is highly problematic, such an approach naturalises mobility as a fact of life and, as Salazar argues, it becomes "a general principle that rarely needs further justification" (2017: 6). However, mobility is not a natural process of our daily lives, and it is not only a 'positive thing'. It is globally practised, but not by all people. Mobility is materially grounded (ibid.) and we need to consider mobility as political-economic processes that are imposed on people, by which people are forced to move or are allowed to move (De Genova, Peutz 2010 in Salazar 2017). Mobility must be perceived as political concept that is one of the constitutors of the government of the EU (Pušnik 2014) and as such, mobility is not only a possibility, an omnipresent right of EU citizens, and a positive consequence of European integration processes, but within the framework of power

6 The percentage of EU citizens included in the 2005 Eurobarometer mobility survey who responded positively, i.e. perceived all three categories as a good thing, was higher than $50 \%$ or just under it (Vandenbrande et al. 2006: 55-58).

7 In Mobile Lives Elliot and Urry (2010:9) write about the need to investigate and discuss various limitations to the myth of mobility and the good life connected to it. 
relations also one of the main tools for governing and building authority in the EU with a direct impact on mobile people in the EU.

\section{ARTISTS' MOBILITY}

Recent discussions of mobility have focused on artists' mobility as a particular form of mobility, and are based on the available scientific literature and EU reports. Artists are one of many identified "movers" (Urry 2007; Salazar 2017) having many needs, drives and objectives in forming and performing mobility, sharing the impacts and consequences of mobility with other mobile people. How is then their mobility different from the mobility of other groups of mobile people, i.e. workers, students, or refugees? Why should we discuss artists' mobility as a particular form inside a mobile world? There are three aspects that define artists' mobility as a particular form of mobility. First, artists' motives for practising mobility are in part different from the motives of other mobile people; second, there is increased interest in the transdisciplinary field of study of cultural and artistic mobility (Mendolicchio 2013). Lastly, the European Commission has recognized artists' mobility as specific form of mobility, supporting projects and studies that tackle various issues connected to the mobility of artists and artworks. Moreover, the DG for Education and Culture has defined mobility of artists as special sub-field within the cultural and creative industries, which will be discussed in the last part of this section. ${ }^{8}$

Similarly to the historical case described in the introduction, contemporary artists are mobile in order to find work, to conduct research or to study, to construct transnational networks, and to change their everyday environment, but not only that. They are mobile because they would like to gain international recognition, to exhibit, to find inspiration, to stoke their creativity, to discover new ways of expression. Artists' mobility, either long or short-term, can be defined by its very specifics related to flexibility, variety of resources ('capital'), transnational connections and networks. Moreover, many researchers argue that mobility is directly linked to artistic practices, and has important impact on the creative process of the individual artist (Kobolt 2008; Kiwan, Meinhof 2011; Mendolicchio 2013; Duester 2013; Kim 2014). Without mobility, many artefacts and a great deal of the architecture we know and enjoy today would simply not exist or would be completely different. Increased and global mobility is further connected to enlarged transnational networks of individual artists and increased transnational connections - which further improves the creative process of the individual artist. Kobolt argues that artists need to travel "in order to have 'an international' career" (2008: 1). 'The need to travel' can be translated into "the need to join and participate in the global/transnational art worlds" (Becker 1982), whereby the art world has been depicted throughout history as a constantly moving and collaborative community (Duester 2013).

According to art critic and theorist Herman Bashiron Mendolicchio (2013) the concept of mobility has already entered the vocabulary and agenda of many international institutions active in the area of arts and culture (see also European Commission 2016) and is one of the more diffused practices that needs to be thoroughly investigated and analysed. Therefore, multiple aspects of cultural and artistic mobility, according to Mendolicchio

See: https://ec.europa.eu/culture/policy/cultural-creative-industries/mobility_en 
(2013: 1), call for a "transdisciplinary field of study that increasingly claims its place in the analysis and research of the social and cultural dynamics of the contemporary world". However, similarly to some other diffused practices established in the contemporary, globalized world, we also need a more inclusive approach to mobility:

[...] the reality is that we are still facing a lack and shortage of narrative, literature and critique on mobility and its implications in the cultural, artistic and social domain. [...] To reflect on mobility today means to widen the perspective, to go beyond the concepts of travel, discovery and displacement; it calls for analysis of the social, political, economic and cultural phenomena linked to it. (Mendolicchio 2013: 1)

However, the interest of scholars of art history, art theory or cultural studies was until recently ${ }^{9}$ primarily oriented towards the impact of 'mobility' on cultural forms and stylistic change, i.e. on influences, mobility being seen as a simple geographical characteristic of the travelling person, moving from point A to point B (Klemenčič 2010, see also Avcioğlu, Flood 2010; Kim 2014). In sociology as well, as Mimi Sheller (2013) argues, the positional understanding of mobility predominates, whereby studies of geographical mobility are limited to specific sub-fields (i.e. migration studies, labour studies). Moreover, those studies "use very traditional methodological approaches to treat mobility as the movement from A to B" (ibid.). However, when we consider a general theory of geographical mobility the key purpose in studying mobility is: 1) in the disclosure of how the content of the line between those two points, i.e. the movements, paths and self-evident/natural and unrecognized meanings, is constructed, and 2) in the filling and interpretation of the empty spaces between A and B (Pušnik 2014: 20) whereby we must consider not only the straight line between $A$ and $B$, but the many in-between points that break the line and can be defined as the C, D, E or F and so on points in the case of highly mobile artists. The type has been identified as (short-term) multi-directional mobility (Duester 2013).

Duester, in her attempt to define artists' mobility, proposed a concise classification of artists' mobility, differentiating between migration and mobility: fixed migration is characteristic of artists who migrate permanently, while short-term mobility is a feature of artists who migrate temporarily or via artist residencies, and ultra or trans-mobility is attributed to those who hop from one city to another or who communicate or collaborate remotely (2013: 112). Artists who move between different locations for cultural, academic, economic or political reasons and needs have developed diverse, often unconventional forms of mobility, transnational connections and consequently ways of life; very often the continuous movement between different locations itself becomes a way of life. Interactions between movement and the arts therefore bring forward conceptual and methodological aspects which are also important for mobility studies. Contemporary mobility processes include new forms of mobility and sociality as the outcome of those interactions, and

9 Art historian David Young Kim has introduced the concept of mobility to the art theory because he is convinced that mobility "was an especially powerful feature of the medieval visual culture" (2014: 1). In his book The Travelling Artist in the Italian Renaissance: Geography, Mobility and Style (2014), Kim juxtaposes mobility with influence (finally suggesting that it be replaced by mobility) and argues how focusing on mobility as a key concept allows art theorists and historians to interpret artworks more completely, emphasizing that mobility "posits difference as style's ontological foundation, unstable as quicksand as that foundation may be" (2014: 36). 
studying them can help us comprehend the mobility process more thoroughly. How can focusing on the interconnection of the arts and mobility help us understand mobility? Following Kiwan and Meinhof (2011) I propose three notions tailored for the understanding of mobility through the arts.

1. If we focus on the mobility of artists we can get a different, alternative insight into mobility as a process, as we can point out "other types of stories" which are more multifaceted and generally circumstantially different from the stories of many other mobile people (migrants and refugees, mobile workers, tourists, soldiers, etc.). Artists' mobility is "one of agency and self-determination, as many artists are highly educated and skilled" (Kiwan, Meinhof 2011: 4); it is transnational and multidirectional, generated not only by economic need, but also by the need "to experience new life and cultures, gain new inspiration, make collaboration/projects with new people and extend the network" (Duester 2013: 108). ${ }^{10}$

2. Focusing on the arts and mobility enables us to explore the complex relationship between the arts and everyday life (mobility policies, impediments to mobility, the impact of globalization and capitalist neo-imperialism on mobile artists and the arts).

3. When studying artists we focus on individuals' career paths and life stories, and therefore move away from studying migrant or ethnic collectives, i.e. communities. Individual artists are not identified only by their ethnic or national affiliations, and that enables us to avoid discourses that essentialize ethnicity (Kiwan, Meinhof 2011).

Finally, let us address the third aspect of artists' mobility as particular form of mobility. The European Commission, recognizing mobility as "becoming an integral part of the regular practice and career of artists and culture professionals" and identifying it "whether for work, study, research, co-production, or participation in a residency or exchange programme", has developed several approaches to promote and support artists' mobility in and to the EU. Within those support schemes, policymakers have not only framed the mobility of artists as part of the cultural and creative industries field ${ }^{11}$ and defined it as one of priorities of the European Agenda for Culture (OMC 2012), they have also set out its basic features (OMC 2012; see also https://ec.europa.eu/culture/policy/cultural-creative-industries/mobility_en). In the praising of the importance of mobility for artists for improving their career opportunities, accessing new markets, creating new jobs, creating networks, etc., an important turn towards neoliberal ideology can be observed. Namely, the focus has been shifted from artists' mobility as an engine of the creative process to mobility as a booster of the EU economy: artists' mobility is primarily needed for economic success, to further contribute to the EU's GDP and create new jobs. In Commissioner Andor's words, artists' mobility, like labour mobility, "contributes to the objectives of the Europe 2020 Strategy by making it easier to fill cyclical and structural labour shortages and offering people opportunities for upward economic and social mobility" (Andor 2014). However, mobility is often hindered by impediments that make mobility not an easy process and certainly not accessible to all, making the opportunities for mobility Andor speaks about rather limited.

10 Duester even argues that "artists are not economic migrants but 'cultural migrants' wanting to experience a new culture, new life, new inspiration" (2013: 113).

11 See: https://ec.europa.eu/culture/policy/cultural-creative-industries/mobility_en 


\section{MOBILITY IS FOR ME BUT NOT FOR YOU?}

In order to have an international career, artists need to travel at least to the nearby art centres, but in most cases to the centres of the international art market (still) defined by Western art institutions, biennales and fairs (Kobolt 2008). Reflecting on migration from the periphery to the centre and especially focusing on representations of peripheral artists in those art centres, Katja Kobolt argues that being peripheral and a migrant (a status ascribed to artists coming from the periphery, i.e. Eastern Europe or other countries to the Western world) within the art world has been represented and appropriated in a way that deprives both the status and the individual artist that are labelled in this way of much of its/their transnational and translational capacity (ibid.). The issues Kobolt raises are also important for our discussion of impediments to mobility, or more simply put: who is able, allowed and/or forced to move and who is not, and under what conditions.

Despite the European Union's quest to abolish many technical, legal and other administrative barriers to free movement of persons, many obstacles still remain, such as the checking of documents at the external Schengen area borders and more recently also controls applied inside the area due to security concerns (European Commission 2017), fragmented national tax systems, separate national markets existing in specific sectors, complex rules for recognition of vocational qualifications, obstacles to accessing healthcare and other social benefits (Eurofound 2014: 35-42). On one hand, technological development, globalization, neoliberalism and inclusive socio-economic and cultural policies promote/encourage the geographical mobility of people, constructing new or more intensive forms of mobility and sociality. On the other, strict migration rules and austere economic policies driven by raising issues of security and xenophobia impose diverse administrative impediments to international mobility.

In the art world, transnationality is conceived differently compared to Western artists if peripheral artists need to submit to a visa regime. "An artist is expected to embody mobility, so the difficulties with obtaining a visa do not really enhance this picture" (Kobolt 2008: 2). The main problems in obtaining a visa arise if people travel frequently; if they are often invited places and on short notice, and therefore need the documents quite quickly; and if they are freelancers or self-employed, and have discontinuous or low incomes. According to the report prepared by the On the Move network (Di Frederico, Le Sourd 2012) all of these features apply to artists: they frequently travel on short notice to take part in exhibitions, to collaborate on opera or dance projects, or to attend art fairs; and artists often have precarious employment status and low income. Also, more administrative obstacles are being set for citizens of EU Member States due to the increased controls at the external borders of the Schengen area and the just recently re-introduced controls inside the area due to security concerns.

Visa regimes are only one problem, as there are several other impediments to mobility, depending on the nationality of the artists, regarding the right to obtain residence and employment documents, the type of employment, the national social security and tax regulations, the information support system, and even the tradition of residencies and cultural politics (the so-called West-East divide; cf. Vujadinovic 2008). Despite the European Union's efforts to harmonize national legislation between Member States, important differences still remain in the areas of taxation, social issues and benefits, health insurance and access to information, and those differences are mainly affecting EU citizens (ERICarts 2008: 12; Eurofound 2014: 35-42). 
Mobile artists are a significantly heterogeneous group of individuals, therefore they are not all affected by impediments to mobility to the same extent. The list of the main impediments to artists' mobility in and to the EU was drafted on the basis of a comparative reading of various expert reports and recommendations written in the last 10 years, covering various art forms ${ }^{12}$ (Poláček 2007; Kobolt 2008; ERICarts 2008; Vujadinovic 2008; IGBK 2010; Recommendations on ... 2010; Di Federico, Le Sourd 2012). ${ }^{13}$ I would substantially exceed the space for this article if I were to provide a more detailed outline or divide them according to their relevancy for EU nationals or non-EU nationals:

1. Application procedures for visas, residence and work permits for third country nationals who are working with an EU organisation and then go on tour with this same organisation inside the EU, or who would like to stay in the EU for a longer period are time consuming, costly, often non-transparent, and heterogenous; work permits are still required for citizens of Croatia in some EU Member States due to transitional arrangements (until 30 June 2020) $;^{14}$

2. Changing or atypical contracts, depending on the type of work or employer; the income is often irregular or unpredictable;

3. Social security regulations and health insurance still depend on national legislation and type of employment;

4. Double taxation, customs duties for art works and different national rules on VAT;

5. The exercising of intellectual property rights is diverse;

6. Lack of information in many areas, especially on regulations and on opportunities for artists;

7. Lack of support for long-term art projects;

8. Lack of reliable statistical data for evidence-based policymaking;

9. The need for capacity training in the arts sector;

10. Differences in capacity and level of support between Member States with higher and lower GDP; difference between those Member States with a long tradition of residencies, programmes and well-developed support tools for artists and those without that tradition (West-East divide).

The reports considered here emphasize another important feature of artists' mobility: it is closely linked to the mobility of artefacts. When moving artworks from one gallery to another between different EU Member States or bringing them to the EU from a third country, a different set of regulations and issues has to be considered. The shipping of artworks is usually costly and demanding: in terms of taxation national rules apply when going

12 Compared to this extensive list of obstacles, the European Commission's attention is often paid only to the three types of so-called administrative practices that create obstacles to the mobility of artists: Schengen visas, social security and cross-border taxation (European Commission 2016).

13 The group of experts who drafted the report on impediments to artists' mobility inside the IGBK network consisted of national experts on art and culture (IGBK 2010).

14 There are important exceptions: self-employed artists do not need a work permit and as posted workers artists can work in all Member States (http://europa.eu/youreurope/citizens/work/ work-abroad/work-permits/index_en.htm). For the next two years EU employment regulations will also remain unchanged for UK citizens entering the EU labour market. A new regime will be established after 2019. 
abroad, and in importing or exporting artworks from or to third countries no exemptions to standard procedures are applied. Customs officers treat artworks like any other goods (IGBK 2010).

In addition to the aforementioned objective issues arising in regard to artists' mobility, several subjective aspects have to be taken into consideration. When abroad and seeking international recognition, individual artists have to deal with alienation, language barriers and cultural differences, even censorship, and a lack of social connections/networks. Furthermore, they are confronted with additional costs, harder living conditions, and many times with an unsupportive social environment (Di Federico, Le Sourd 2012; Konjikušić 2016). The regulation of mobility and existing impediments to it have been critically assessed not only by various experts in the field. They have also been explored and critically addressed by mobile artists, becoming the subject of artworks. The time-consuming, often costly and therefore exhausting procedures of visa regimes have been transformed into artistic expression, for example by Tanja Ostojić, a performance artist and feminist from Serbia, and Leila Čmajčanin, artist and performer from Sarajevo. Tanja Ostojić has drawn inspiration for several artistic works from her experience as a non-European Union citizen and artist who had to travel from her hometown in Serbia to Germany through Slovenia and France. Her works After Courbet, L'Origine du Monde, also named EU Panties (2005), Waiting for a Visa (performance in front of Austrian Consulate in 2000 in Belgrade), Illegal Border Crossing (art-action on the Slovenian-Austrian Border in 2000) or the performance piece Looking for a Husband with an EU Passport (2000-2003) all express the artist's Euroscepticism and underline the arrogance of the EU bureaucracy towards non-EU citizens. Leila Čmajčanin together with two other female artists from Bosnia and Herzegovina has created several exhibitions on the topic of the Global South (as part of the City of Women festival in 2009 in Ljubljana). If they wanted to see the exhibitions, visitors first had to obtain a visa issued by the artists on the basis of the same criteria they had to meet when entering the EU. In describing the piece, Kobolt states that "by checking if the visitors to her exhibition - artists, curators or aliens, it makes no difference to her - have enough funds, have a certified invitation, are in good health, etc., she makes visible the regulations a peripheral artist encounters when trying to enter the 'international' art market" (2008: 2).

\section{CONCLUSION: TOWARDS THE MOBILE FUTURE}

In this survey article I have analysed and compared various scientific articles, legal documents, government and expert reports with the aim to outline some key features of mobility's habitus as part of globalized art worlds and at the same time to highlight the diverse perceptions of the (artists') mobility concept. Artists' mobility can be defined through three sets of identifiers: specific motives for mobility (why artists are mobile), academic interest and formation of the interdisciplinary research field of cultural and artistic mobility, and the definition of the mobility of artists as part of the cultural and creative industries. According to the analysis of the reports on the promotional and support mechanisms for artists' mobility and their counterparts, critical assessments of these mechanisms have shown that mobility - including artists' mobility - is seen as a very positive process that needs to be financially and politically supported and further promoted on the decision-making level. It is considered as one of many "little boosters" of the EU economy, as mobile artists 
and cultural producers working in the cultural and creative industries not only improve their career opportunities and earn their living, but most importantly contribute to the creation of new jobs and even to the EU's GDP. ${ }^{15}$ However, when analysing the reports of experts and expert groups involved in assessing and researching artists' mobility, the picture is not so clear and clean. According to them, artists' mobility is very important for artists and cultural professionals also for other, non-economic reasons: it enables them to gain international recognition, they can exhibit in international art capitals, they get inspiration, it spurs their creativity, they can discover new ways of expression. But there are many obstacles which hinder mobility, most of them a direct result of other political and economic decisions. Analysis has shown that mobile artists can seize a lot opportunities by being active in the transnational/globalized art worlds, but at the same time they face many challenges imposed on them by the same art world and by mobility policies per se.

Many of the reports reviewed emphasize that despite the rather broad legal framework and ongoing attempts at harmonization of the same framework between Member States, the EU has failed to eliminate or even diminish impediments to the mobility of artists. Social security issues, taxation, language and cultural differences, limited access to information, and visas and work permits for persons from third countries and outside the Schengen area are still defined as the main obstacles to the free movement of workers in the arts and culture sector, but also in many other sectors (Poláček 2007; Kobolt 2008; IGBK 2010; Holland et al. 2011).

Yet there is another aspect that needs to be emphasized in regard to the perception of artists' mobility. Kim, referring to the art world of the Renaissance, argues that "mobility, as an 'external' force acting upon a society, realigns the bonds among artists, patrons, competitors, audience" (2014: 6). Moreover, mobility realigns economic and power relations (cf. Pušnik 2014; Salazar 2017), which is also closely connected to the manifestation of the political on and in the arts. Artists' mobility is actually labour mobility, since within global neo-liberal power relations artists are considered labourers, most often precarious ones (Vishmidt 2011; Praznik 2016). The discourses used in the academic literature and research, but also in the arts (i.e. on information platforms for artists), emphasize this explicitly: the mobility of the arts and culture sector, arts and culture professionals, arts and culture entrepreneurs, highly skilled workers like artists, self-employed artists who use A1 forms, the project Artist on a Business Trip, and finally, cultural and creative industries. ${ }^{16}$ It is important to emphasize that we are not dealing only with terminology, but with a specific discourse (and also policies) that operationally places artists in the category of labourers or workers. Artists are no longer treated as being outside conventional rules, but are subjected to modern neoliberal market mechanisms and their mobile practices are regulated by EU mobility policy. This indicates that we are dealing with the process of commodification or financialization (Vishmidt 2011) of artists' labour. However, artists that are self-employed and many others do not receive a wage for their work and many are poorly paid or working as precarious workers, whereby mobility, although depicted as an opportunity, is randomly turned into a costly and stressful endeavour. These topics are important for the further discussion of mobility and will need to be researched more thoroughly in the future.

15 See: https://ec.europa.eu/culture/policy/cultural-creative-industries_en

16 All quotations can be found in the various references used in this article and listed in the list of references at the end. 


\section{REFERENCES}

Andor, Laszlo (2014). Labour Mobility in the EU, http://europa.eu/rapid/press-release_ SPEECH-14-622_en.htm (11. 1. 2017).

Avcioğlu, Nebahat, Flood, Finbar Barry (2010). Introduction. Globalizing Cultures: Art and Mobility in the Eighteenth Century. Ars Orientalis 39, 7-38.

Barroso, Jose Manuel (2006). 2006 European Year of Worker's Mobility, http://europa.eu/ rapid/press-release_SPEECH-06-109_en.htm (11.1.2017).

Bauman, Zygmunt (1998). Globalization: The Human Consequences. New York: Columbia University Press.

Becker, Howard S. (1982). Art Worlds. Berkeley, Los Angeles, London: University of California Press.

Birtchnell, Thomas, Caletrío (2014). Elite Mobilities. Abingdon, New York: Routledge.

Büscher, Monika, Urry, John, Witchger, Katian (2011). Mobile Methods. London, New York: Routledge.

Čoralić, Lovorka, Katalinić, Vjera, Katušić, Maja (2016). Bubnjari, timpanisti, trubači i pifaristi: Glazbena pratnja u mletačkim prekojadranskim kopnenim postrojbama u 18. stoljeću. Arti musices 47/1-2, 27-78.

Di Frederico, Elena, Le Sourd, Marie (2012). Artists' mobility and visas: A step forward. Final report of On the Move's workshop on artists's mobility and Schengen visas. On the Move, www.on-the-move.org (25. 2. 2017).

Duester, Emma (2013). Artist Mobility and the Baltic Cities: Revealing a Transnational Art World. Networking Knowledge 6/4, 107-120.

ECFIN (2015). Quarterly Report on the Euro Area, 14/1, http://ec.europa.eu/economy_finance/publications/qr_euro_area/2015/qrea1_en.htm (20.1.2017).

Elliot, Anthony, Urry, John (2010). Mobile Lives. London, New York: Routledge.

ERICarts (2008). Mobility Matters. Programmes and Schemes to Support the Mobility of Artists and Cultural Professionals. Final Report. Bonn: ERICarts.

European Commission (2016). Mobility of Artists and Culture Professionals, http://ec.europa.eu/culture/policy/cultural-creative-industries/mobility_en (1.2. 2017).

European Commission (2017). Back to Schengen, http://europa.eu/rapid/press-release_IP17-124_en.htm (1.6.2017).

Eur-Lex (2006). European Year of Workers Mobility 2006, http://eur-lex.europa.eu/legal-content/SL/TXT/?uri=URISERV:c11333 (24. 2. 2017).

EUROFOUND (2014). Labour Mobility in the EU: Recent Trends and Policies. Luxembourg: Publications Office of the European Union.

Goldin, Ian, Camron, Geoffrey, Balarajan, Meera (2011). Exceptional People: How Migration Shaped our World and will Define our Future. Princeton, Oxford: Princeton University Press.

Holland, Dawn, Fic, Tatiana, Rincon-Aznar, Ana, Stokes, Lucy, Paluchowski, Pawel (2011). Labour Mobility within the EU: The Impact of Enlargement and the Functioning of the Transitional Arrangements. Final Report, http://www.precarious-work.eu/sites/default/files/effat/files/studies/Labour_mobility_report_July_2011_en.pdf (24. 2. 2017).

IGBK (2010). Challenges for Mobility: Recommendations from the Visual Arts Sector. Berlin. Jaki, Barbara (2010). Predgovor. Robbov vodnjak: Zgodba mestnega simbola (ed. Matej Klemenčič). Ljubljana: Narodna galerija. 
Kalčić, Špela, Juntunen, Marko, Rogelja, Nataša (2013). Marginal Mobility: A Heuristic Tool for Comparative Study of Contemporary Mobilities. Dve domovini / Two Homelands 38, 7-20.

Kim, David Young (2014). The Traveling Artist in the Italian Renaissance: Geography, Mobility and Style. New Haven: Yale University Press.

Kiwan, Nadia, Meinhof, Ulrike Hanna (2011). Music and Migration: A Transnational Approach. Music and Arts in Action 3/3, 3-20.

Klemenčič, Matej (2010). Robbov vodnjak: Zgodba mestnega simbola. Ljubljana: Narodna Galerija.

Kobolt, Katja (2008). Art and Migration - the Troubled Relations between the Centre and the Periphery. Living on a Border, KITCH, www.kitch.si/livingonaborder.net/node/41 (11. 1. 2017).

Konjikušić, Davor (2016). Tanja Ostojić: Ne pristajem na cenzuru, Novosti, 24. 8., http:// www.portalnovosti.com/tanja-ostojic-ne-pristajem-na-cenzuru (29. 8. 2016).

Mendolicchio, Bashiron Herman (2013). Art and Mobility. An Introduction. Art + mobility, http://artmobility.interartive.org/art-and-mobility-editorial/ (22. 3. 2017).

OMC (2012). Report on Building a Strong Framework for Artists' Mobility: Five Key Principles, Open Method of Coordination, Working Group of EU Member States' Experts on Mobility Support Programmes, http://ec.europa.eu/assets/eac/culture/library/reports/ artist-mobility-report_en.pdf (22.4.2017).

Poláček, Richard (2007). Study on Impediments to Mobility in the EU Live Performance Sector. MOBILE.HOME.

Praznik, Katja (2016). Paradoks neplačanega umetniškega dela: Avtonomija umetnosti, avantgarda in kulturna politika na prehodu v postsocializem. Ljubljana: Sophia.

Pušnik, Tomaž (2014). Mobilna Evropska unija - vzpostavljanje in delovanje oblasti prek mobilnosti. Magistrsko delo. Ljubljana: Univerza v Ljubljani, Fakulteta za družbene vede.

Recommendations on Culture Mobility (2010). From the 4 Arts Mobility Pilot Projects, http://ec.europa.eu/assets/eac/culture/policy/cultural-creative-industries/documents/ cultural-mobility_en.pdf (5. 6. 2017).

Salazar, Noel B. (2017). Key Figures of Mobility: An Introduction. Social Anthropology 25/1, 5-12.

Sheller, Mimi (2013). Sociology after the Mobilites Turn. The Routledge Book of Mobilities (eds. Peter Adey, David Bissell, Kevin Hannam, Peter Merriman, Mimi Sheller). London: Routledge, https://www.routledgehandbooks.com/doi/10.4324/9781315857572. ch3\#ref4_6.

Sheller, Mimi, Urry, John (2016). Mobilizing the new Mobilities Paradigm. Applied Mobilities 1/1, 10-25.

Thyssen, Marianne (2015). Speech by Commissioner Marianne Thyssen on Europe's vision for fair labour mobility, http://europa.eu/rapid/press-release_SPEECH-15-6074_ en.htm (11. 1. 2017).

Urry, John (2000). Sociology Beyond Societies: Mobilities for the Twenty-first Century. London, New York: Routledge.

Urry, John (2007). Mobilities. Cambridge, Malden: Polity.

Vandenbrande, Tom, Coppin, Laura, van der Hallen, Peter (2006). Mobility in Europe. Analysis of the 2005 Eurobarometer Survey on Geographical and Labour Market Mobility. Dublin: EUROFOUND. 
Vishmidt, Marina (2011). Working Artists in the Greater Economy. Motley Crew 1, Autumn, 15-21.

Vujadinovic, Dimitrije (2008). Mobility of Artists and Cultural Professionals in South Eastern Europe. Trans Europe Halles, http://teh.net/resource/cultural-mobility-studies/ (22. 2. 2017).

\section{POVZETEK}

\section{MOBILNOST UMETNIKOV V EU: MED PRILOŽNOSTMI IN OVIRAMI Kristina TOPLAK}

Avtorica se v članku loteva različnih vidikov posebne oblike mobilnosti, to je mobilnosti umetnikov. Z namenom orisati ključne značilnosti habitusa mobilnosti umetnikov, o njej razpravlja v kontekstu evropskih politik mobilnosti in znanstvenih pogledov na mobilnost na eni in kritičnega vrednotenja mobilnosti umetnikov na drugi strani. Pri tem razmislek o mobilnosti umetnikov postavlja v presek med priložnostmi za mobilnost in ovirami zanjo. Mobilnost umetnikov v članku utemeljuje s pomočjo treh vidikov: 1) z vidika motivov za mobilnost: mobilni umetniki in ustvarjalci v kulturi navajajo poleg specifično ekonomskih motivov za mobilnost številne specifične motive, ki definirajo njihovo mobilnost (razstavljajo lahko v svetovnih umetniških prestolnicah, postanejo mednarodno umetniško prepozna(v)ni, mobilnost spodbuja ustvarjalnost, ustvarjanje novih stikov, pridobivanje navdiha za umetniška dela ipd.); 2) z vidika raziskovalnega pokritja tega področja: vse večje zanimanje za mobilnost umetnikov vlada tudi med raziskovalci, kar narekuje pojav novega interdisciplinarnega raziskovalnega polja - kulturne in umetniške mobilnosti (pri čemer so zajeti tudi mobilnost artefaktov, kulturnih vzorcev in podobno); in 3) s stališča tvorcev politike mobilnosti oziroma ekonomije kulture: prepoznavnost mobilnosti umetnikov kot posebne veje v okviru kulturne in kreativne industrije, kot jo definira Evropska komisija.

Avtorica prav tako ugotavlja, da je mobilnost, zlasti delovna, promovirana in ovrednotena kot ekonomski in politični temeljni kamen Evropske unije. Hkrati je tudi dojeta kot ključna za njuna prihodnja razvoj in rast. Ob konceptu mobilnosti se je oblikoval specifični politični, akademski in javni diskurz, ki odslikava največkrat enoplastno, velikokrat le pozitivno podobo mobilnosti. Mobilni posamezniki pa se na drugi strani soočajo z veliko ovirami, ki jim preprečujejo mobilnost, pri čemer so v transnacionalnih umetnostnih svetovih aktivni umetniki še zlasti ranljivi. Članek tako osvetljuje razkorak, ki nastaja med dojemanjem mobilnosti, kot jo oblikujejo politični in javni diskurz ter akademski pristopi $\mathrm{k}$ njenemu preučevanju in kot jo definirajo ter problematizirajo umetniki in strokovni delavci v analizah stanja na področju mobilnosti umetnikov. Diskusija v članku temelji na številnih in raznolikih pisnih virih (akademski članki, EU poročila, pravni dokumenti in direktive EU, poročila in priporočila strokovnih skupin, ki delujejo na področju mobilnosti umetnikov, tudi številni spletni viri). 